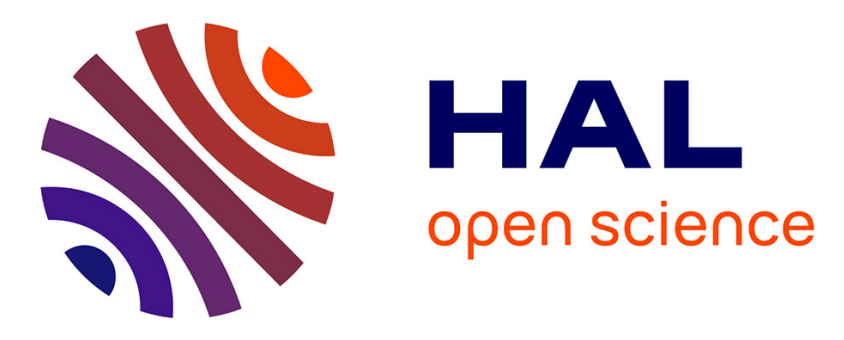

\title{
Estimation of landslides activities evolution due to land-use and climate change in a Pyrenean valley
}

Rosalie Vandromme, Séverine Bernardie, Thomas Houet, Marine Grémont, Gilles Grandjean, Yannick Thiery

\section{To cite this version:}

Rosalie Vandromme, Séverine Bernardie, Thomas Houet, Marine Grémont, Gilles Grandjean, et al.. Estimation of landslides activities evolution due to land-use and climate change in a Pyrenean valley. EGU General Assembly 2016, Apr 2016, Vienne, Austria. pp.EGU2016-13148. hal-01286353

\section{HAL Id: hal-01286353 https: / hal-brgm.archives-ouvertes.fr/hal-01286353}

Submitted on 10 Mar 2016

HAL is a multi-disciplinary open access archive for the deposit and dissemination of scientific research documents, whether they are published or not. The documents may come from teaching and research institutions in France or abroad, or from public or private research centers.
L'archive ouverte pluridisciplinaire HAL, est destinée au dépôt et à la diffusion de documents scientifiques de niveau recherche, publiés ou non, émanant des établissements d'enseignement et de recherche français ou étrangers, des laboratoires publics ou privés. 


\title{
Estimation of landslides activities evolution due to land-use and climate change in a Pyrenean valley
}

\author{
Rosalie Vandromme (1), Séverine Bernardie (1), Thomas Houet (3), Marine Grémont (2), Gilles Grandjean (), \\ and Yannick Thiery () \\ (1) BRGM, RIS/RMT, Orléans, France (s.bernardie@brgm.fr), (2) BRGM, Montpellier, France, (3) GEODE UMR 5602 \\ CNRS Université Toulouse, France
}

Global changes would have impacts worldwide, but their effects should be even more exacerbated in areas particularly vulnerable. Mountainous areas are among these vulnerable territories. Ecological systems are often at a fragile equilibrium, socio-economical activities are often climate-dependent and climate-driven natural hazards can be a major threat for human activities. In order to estimate the capacity of such mountainous valleys to face global changes (climate, but also climate- and human- induced land-use changes), it is necessary to be able to evaluate the evolution of the different threats. The present work shows a method to evaluate the influences of the evolution of both vegetation cover and climate on landslides activities over a whole valley until 2100 , to propose adequate solutions for current and future forestry management.

Firstly, the assessment of future land use is addressed through the construction of four prospective socio-economic scenarios up to 2050 and 2100, which are then spatially validated and modeled with LUCC models.

Secondly, the climate change inputs of the project correspond to 2 scenarios of emission of greenhouse gases. The used simulations available on the portal DRIAS (http://www.drias-climat.fr) were performed with the GHG emissions scenarios (RCP: Representative concentration pathways, according to the standards defined by the GIEC) RCP 4.5 and RCP 8.5.

The impact of land use and climate change is then addressed through the use of these scenarios into hazards computations. For that we use a large-scale slope stability assessment tool ALICE which combines a mechanical stability model (using finite slope analysis), a vegetation module which interfere with the first model, to take into account the effects of vegetation on the mechanical soil properties (cohesion and over-load), and an hydrogeological model. All these elements are interfaced within a GIS-based solution.

In that way, future changes in temperature, precipitation and vegetation cover are analyzed, permitting to address the direct and indirect impacts of global change on mountain societies. The whole chain is applied to a $100-\mathrm{km}^{2}$ Pyrenean Valley, for the ANR Project SAMCO (Society Adaptation for coping with Mountain risks in a global change COntext), as a first step in the chain for risk assessment for different climate and economical development scenarios, to evaluate the resilience of mountainous areas. 